\title{
A.4 University of Tokyo Library, Ms. $201^{5}$
}

A Nepalese paper manuscript of 201 folios. Undated; seemingly from the $19^{\text {th }}$ century. In the final colophon it is called Dhāraṇisaṃraha-PurāṇaMahāyānasūtra. ${ }^{6}$

1. Pañcarakṣā-mahādevyā sādhana 8v [151]

2. Vasudhārāyā nāmāṣțottaraśataka-buddhabhāṣita 10v [97]

3. Vajravidāraṇa-hṛdayamantra-dhāraṇī 13r [98]

4. Gaṇapati-hṛdayā-nāma-dhāraṇī 14v [99]

5. Ușṇișavijayā-nāma-dhāraṇī 17r [100]

6. Piśāciparṇasavarīmahāmārīpraśamanī-nāma-dhāraṇī 18r [85]

7. Mārīcì-nāma-dhārạ̣i 19v [102]

8. Grahamātṛkā-nāma-dhāraṇī 26v [103]

9. Rāhavagrahaśānti-upadrava-nāma-dhāraṇī 28r

10. Ketugrahaśānti-nāma-dhāraṇī 29v

11. Sarvatathāgatoṣnịiṣasitātapatrā-nāmāparājitā-mahāpratyañgirā-nāmadhāraṇī-vidyārājñ̄i 40v [83]

12. Vajramahākālatantrarāja-nāma 49r

13. Abhimantraphaladā-siddhidāyanī-vajrayoginīnairātmāguhyeśvarī-mantranāma-dhāraṇī 51r

14. Ekajațā-nāma-dhāraṇī 54v [113]

15. Tārābhaț̣ārikāyāḥ sragdharā-stuti 60v

16. Nāmasamgīti-hṛdaya $61 \mathrm{r}$

17. Tattvajñānasaṃsiddhi-nāma-svādhișțhāna-krama 65v

18. Bhadracari-mahāpraṇidhānaratnarāja 71r [70]

19. Aparimitāyur-nāma-mahāyānasūtra 81r [47]

20. Pañcaviṃśatikā-prajñāpāramitā-hṛdaya-nāma-dhāraṇī 84r [101]

21. Vajrasattvakāyasya tathāgatavyāptaśata $85 \mathrm{v}$

22. Sugatāvadānokta-saptabuddha-stuti $86 \mathrm{v}$

23. Mūlavidyāmantrasiddhi-dhāraṇī 87r [1]

5 Available online: http://picservice.ioc.u-tokyo.ac.jp/03_150219 UT-library_sanskrit_ms/MF13 _24_012 MF13_24_012/?pageId=001 (accessed March 2020). Titles given with minor standardizations. Corresponding text numbers in Cambridge Ms. Add. 1326 are given in square brackets (there is a chance of inconsistencies in the case of texts which appear by the same title more than once).

6 Matsunami 1965: 81. This manuscript lacks a detailed colophon. Note that Pandey 1990b: 4-6 describes a collection called Dhāraṇisaṃgraha-Purāna-Mahāyānasūtrarāja. It is reported to contain 108 texts written on 282 folios but only 36 titles are listed. 
24. Amitābhasya-nāma-dhāraṇī 87v [6]

25. Śākyamunibhāṣito bhagavanto mañjūśrījñānasattvasya paramārthānāmasaṃīti 95v [57,115]

26. Mañjuśrīpratijñā-nāma-dhāraṇī 96r [58]

27. Amṛtabhakṣā-nāma-dhāraṇī 96r [117]

28. Arapacanamañjuśrī-sādhana-nāma-dhāraṇī 96v [123]

29. Maitreyapratijñā-nāma-sūtra-dhāraṇī 96v [87]

30. Maitreya-nāma-dhāraṇī 96v [18,124]

31. Gaṇḍavyūha-nāma-dhāraṇī 104r [9]

32. Ekajaṭā-dhāraṇī 108v [113]

33. Tārābhaț̣ārikāyā nāmāṣțottaraśataka-buddhabhāṣita 111v

34. Tārādevyā namaskāraikaviṃśati-stotra 113r

35. Ekajaṭā-dhāraṇī 119r [113]

36. Svayambhūcaityabhaț̣̄ārakoddeśe mahāprabhāvavardhano-nāmāṣțamapariccheda $137 \mathrm{r}$

37. Upoṣadāvadāna 142r

38. Mahāpratisarāyāḥ prathama-mantra-dhāraṇī $147 \mathrm{r}^{7}$ [76]

39. Mahāsāhasrapramardanī-mantra-dhāraṇī-dvitīya 148r [78]

40. Mahāmāyūrī-vidyārājñī tṛtīya-mantra-dhāraṇī 150v [79]

41. Mahāŝītavatī-daṇḍadhāraṇì-caturtha-mantra-dhāraṇī 152r [80]

42. Mahāmantrānusāraṇī-vidyārājñ̄ì-pañcama-dhāraṇī 153r [81]

43. Ugratārā-stotra $154 \mathrm{r}$

44. Mahāsaṃvara-hṛdaya-dhāraṇī 155v

45. Mahāvajravārāhī-nāma-dhāraṇī 156v [105]

46. Vajrabhairavakālacakrasya mantrahṛdaya-nāma-dhāraṇī 159r

47. Vajratārā-nāma-dhāraṇī 160v [126]

48. Hevajra-nāma-dhāraṇī 161v [174]

49. Ugratārā-nāma-dhāraṇī 162r [127]

50. Vidyādharidevī-upahṛdaya $163 \mathrm{r}$

51. Kurukullā-nāma-dhāraṇī 163v [95]

52. Yogāmbarasya karmarāja-nāma-dhāraṇī 164r [120]

53. Mahāsarasvatī-nāma-dhāraṇī 165r [94]

54. Ușṇīṣacakravartī-nāma-dhāraṇī 165v [50]

55. Daśakrodha-nāma-dhāraṇī 166r [128]

56. Vajrapāṇibhāṣita-mahārakṣā-nāma-dhāraṇi 166v [49]

57. Vajranairātmādevī-hṛdaya-mantra-dhāraṇi $167 \mathrm{v}$

58. Cakrasamvvarasya tantrāntapațala-hṛdaya 168v

7 Note that folio 144 is missing. 
59. Kurukullāyā rasāyana-tantra-kalpa-saptama 187r

60. Bhagavatyāryatārāyāḥ kurukullā-kalpāșțama 191v

61. Megha-dhārạ̣ī 192r

62. Mañjuśrīpratijñā-nāma-dhāraṇī 192v [58]

63. Sợaśabhujamahākāla-sādhana $195 \mathrm{v}$

64. Siṃhamukhi-nāma-dhāraṇī 197v

65. Siṃghamukhi-nāma-dhāraṇī 201v 